\title{
correspondence
}

\section{DPAG needs public interest representatives}

SiR,-I refer to your article (29 March, page 387) "Britain's shadow science minister believes in experts."

If the substance of your article really does represent the views of Mr Carlisle, perhaps the headline would have more accurately read "believes in non-trade union experts" or even "anti-trade union experts."

The plain fact of the matter is that the Dangerous Pathogens Advisory Group (DPAG), which does not have representatives from the trade unions or from the community, and consists solely of experts in the sense that the Conservative shadow minister uses the word, has in safety terms been a disaster. GMAG, which does include representatives of the public and trade unions, has been able to exercise a positive, constructive and effective role in the area in which it operates. The comparison is dramatic.

Of twelve laboratories cleared by the non-statutory "leave it to the experts" DPAG (which excludes trade union representatives) as safe to handle Category A pathogens, the Health and Safety Executive has now served prohibition/improvement notices on three. No such problems have arisen in laboratories working in the field of genetic manipulation experimentation! These have been controlled from the outset by close cooperation between the Health and Safety Executive and the Genetic Manipulation Advisory Group which does, of course, include the Trades' Union Congress (TUC) nominees and representatives of the community. This is because trade unions' organising staff doing such work can provide experts as good as any, with the added advantage of links with democratic organisations possessing economic and political clout. This makes it possible to defend the interests of the public and employees to a degree DPAG has either been unwilling or unable to do. The consequences have been tragic as we well know from the smallpox occurrence at Birmingham, and the laboratory now closed as unsafe was cleared by a DPAG system $\mathrm{Mr}$ Carlisle evidently holds in such high regard.

Would it be fair to conclude that $\mathrm{Mr}$ Carlisle is moved by fossilised Conservative policies, rather than the health and safety of the community and of the work people concerned. Yours faithfully,

R. A. BIRD

Association of Scientific, Technical and Managerial Staffs,

London.

\section{International energy programmes need coordinating}

Sir,-In the face of the approaching threat of a world energy shortage Professor Rotblat's "Call for world (non-nuclear) energy organisations" (1 March, page 4), to coordinate and stimulate the development of non-nuclear sources of energy seems a positive step. But will this include oil, natural gas and coal? If Professor Rotblat is referring only to the so-called renewable cnergy sources any means of increasing their contribution beyond the $2 \%$ of world energy supply by the year 2000 suggested in a recent report to the Club of Rome deserves encouragement.

Something is, however, already being done: the World Bank Group has lent $\$ 10$ billion since 1948 for building power plants. In 1978 alone it lent $\$ 1,146$ million for energy and power projects in developing countries-all non-nuclear (almost 20 times the 1978 budget of the

IAEA). Furthermore the Centre for Natural Resources, Energy and Transport at the United Nations, as well as the UN Regional Commissions, actively promote all non-nuclear forms of energy, as do UNESCO, UNIDO and UNEP and the US/AID. What is needed is a greater concentration and coordination of the programmes of existing agencies-not a new one.

If the world is to avoid a damaging energy crisis with widespread unemployment, protectionism and even armed conflict over limited energy supplies, all available energy sourcesincluding nuclear power-must be developed, and energy conservation programmes increased. Professor Rotblat is then misguided in attacking what he calls the "promotional" activities of the International Atomic Energy Agency.

In fact a major role of the IAEA is in developing an institutional regime within which nuclear power can be used safely and securely. IAEA's 1979 'assessed' budget provides approximately $\$ 20$ million for regulatory activities (of which $\$ 15.6$ million are for safeguards against proliferation) compared with $\$ 3.4$ million for the division that deals with nuclear power and reactors.

The other promotional activities of the IAEA are in subjects like theoretical physics and fusion or for application of radio-isotopes in biology, medicine, food and agriculture. They are designed to help the great majority of the developing countries for which nuclear power is hardly, if at all, in prospect.

In addition to the "assessed" budget there is a voluntary technical assistance budget. In $1977,21.9 \%$ of this went to nuclear engineering and technology (chiefly training in the safe operation of nuclear plants) compared with about $40^{\circ}{ }^{\prime}$ for application of isotopes in agriculture, hydrology, medicine, etc.

Professor Rotblat's main contention that a large expansion of nuclear power would greatly increase the chance of nuclear war, since almost every nation would have access to plutonium, flies in the face of the facts of history, economics and technological development. All nuclear weapon programmes have been based on series of special facilities dedicated solely to military purposes and quite independent of the civil power programmes of the countries concerned. This separation becomes even more marked as time goes on. It is far cheaper, easier and less conspicuous to build and operate the small purpose-built plants needed for a modest weapon programme than to engage in commercial nuclear power. The difference in cost is of the order of twenty to one. Stopping nuclear power would not cause a moment's pause in the nuclear armament and submarine programmes of the weapon states.

A more immediate threat to world peace comes from competition over limited supplies of oil. According to a report in the Financial Times,

26 February, 1979, the US Defence

Secretary has said that in protection of vital Middle East oil supplies "we will take any action that is appropriate, including military force". By increasing energy supplies and reducing the pressure of demand over scarce resources nuclear power will prove to be a stabilising factor in international affairs.

Professor Rotblat may not think much of treaties and international safeguards, but the fact is that the rate of proliferation of nuclear weapons has declined each decade since 1944. At the same time almost all the industrial and many of the leading developing countries of the world have benefitted from the peaceful use of nuclear technology. The danger of nuclear war comes from the arsenals of the great powers and not the power plants of the small. Yours faithfully,

London, SW15.

G. Greenhalgh

\section{Recombinant DNA dangers and wild $E$. coli}

Sir,--Many scientists engaged in recombinant DNA research now expound the doctrine, referred to by Eleanor Lawrence in her report on the COGENE meeting at Wye (12 April, page 590), that the dangers that might arise during the course of their experiments cannot be greater than the dangers posed by working with the most dangerous organisms employed in those experiments. This might well be so when the recipients of genetic material are 'enfeebled' organisms such as $E$. coli $\mathrm{K} 12$, but it could be far from true if other recipients were employed, deliberately or accidentally. For example, to my mind. the implantation of efficiently expressible genes for botulinum toxin production in wild $E$. coli or other organisms that can multiply relatively freely in the food or in the intestinal tract of man or animals represents a much greater danger than the presence of these genes in Clostridium botulinum itself. Yours faithfully,

H. Williams Smith

Houghton Poultry Research Station.

Huntingdon, $U K$ 